\title{
First report of Mungbean yellow mosaic India virus on Lima bean affected by yellow mosaic disease in Nepal
}

\author{
M. S. Shahid • M. Ikegami • K. T. Natsuaki
}

Received: 25 January 2012 / Accepted: 20 April 2012 / Published online: 8 June 2012

(C) Australasian Plant Pathology Society Inc. 2012

\begin{abstract}
A begomovirus associated with yellow mosaic disease in lima bean (Phaseolus lunatus) was cloned, sequenced. The virus has a bipartite genome of which DNA-A is 2745 nucleotides length and DNA-B 2669 nucleotides, and has a typical bipartite begomovirus genomic organization from the Old World. The sequences showed the highest levels of nucleotide identity (99.2\% for DNA-A and $98.9 \%$ for the DNA-B) to the 'Indian' strain of Mungbean yellow mosaic India virus (MYMIV).
\end{abstract}

Keywords Phaseolus lunatus · Geminivirus ·

Begomovirus · Bipartite

\section{Introduction}

Geminiviruses have circular, single-stranded DNA (ssDNA) genomes that are encapsidated in characteristic twinned quasi-icosahedral particles. It is the family Geminiviridae that "consist" of four genera (Topocuvirus, Curtovirus, Mastrevirus or Begomovirus) based upon genome arrangement,

M. S. Shahid $(\bowtie) \cdot K$. T. Natsuaki

Department of International Agricultural Development,

Tokyo University of Agriculture,

1-1-1, Sakuragaoka, Setagaya-ku,

Tokyo 156-8502, Japan

e-mail: shafiqinayat@yahoo.com

M. S. Shahid

Department of Biosciences,

COMSATS Institute of Information Technology,

Sahiwal 57000, Pakistan

M. Ikegami

NODAI Research Institute, Tokyo University of Agriculture,

Tokyo 156-8502, Japan insect vector and sequence relatedness (Stanley et al. 2005). Begomoviruses are transmitted by the whitefly Bemisia tabaci and are the most economic damage among all Geminiviruses. All begomoviruses originating from the New World (NW) typically have genomes consisting of two components, known as DNA-A and DNA-B, both of which are required for virus infectivity. In the Old World (OW), although there are a small number of bipartite begomoviruses, the majority have only a single genomic component, which is a homolog of the DNA-A of the bipartite begomovirus. A small proportion of these monopartite begomoviruses are truly monopartite; their single component induces disease in plants in the field, such as Tomato leaf curl virus in Australia (Dry et al. 1993). Both DNA-A and DNA-B components of bipartite begomoviruses share little sequence similarity with the exception of an approximately $200 \mathrm{bp}$ sequence with high nucleotide identity (80-100\%) that contains the origin of virion-strand DNA replication.

The begomovirus genomes are typically $2.8 \mathrm{~kb}$ nucleotides in length and encode genes both in complementary and virion sense from a non-coding intergenic region that contains promoter sequences and the origin (ori) of virionstrand DNA replication. The ori consists of a predicted hairpin structure that contains the absolutely conserved (for geminiviruses) nonanucleotide (TAATATTAC) loop sequence and repeated motifs upstream known as iterons. The virion-sense strand encodes the genes required for insect transmission and movement in plants, coat protein (CP) and V2 protein. The complementary-sense strand encodes the following proteins: the replication-associated protein (Rep) required for viral DNA replication, which is a rolling circle replication initiator protein that recognizes the iterons and nicks within the nonanucleotide sequence to initiate replication (Hanley-Bowdoin et al. 2004); the transcriptional activator protein (TrAP), which for bipartite begomoviruses 
Fig. 1 Characteristic yellow vein symptoms of begomovirus infection of Phaseolus lunatus
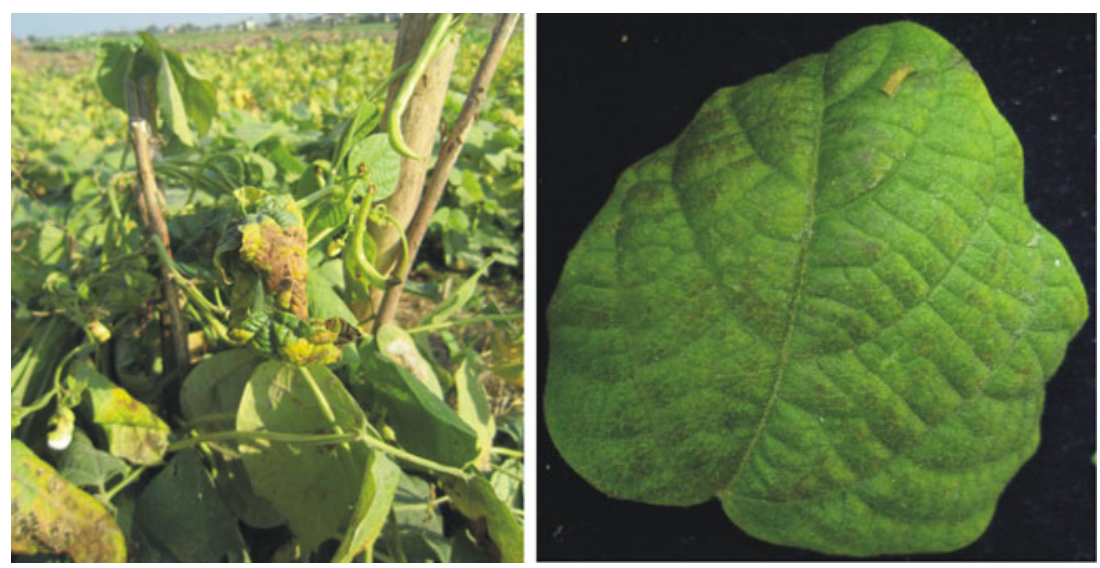

up-regulates the late (virion-sense) genes, is a suppressor of post-transcriptional gene silencing (PTGS) and overcomes virus-induced hypersensitive cell death (Hussain et al. 2007); the replication enhancer protein (REn), which is involved in creation of an environment favorable for virus replication (Settlage et al. 2005); and the C4 protein, for which the function remains unclear but for some viruses is a pathogenicity determinant and a suppressor of PTGS (Saeed et al. 2008).
Lima bean (Phaseolus lunatus) is an important food crop widely distributed in areas of Nepal and frequently exhibits yellow mosaic symptoms that are typical of begomoviruses. $P$. lunatus plants that showed yellow vein and mosaic symptoms were collected from different fields in the vicinity of Chitwan, Nepal (Fig. 1). Total genomic DNA was extracted from symptomatic and non-symptomatic leaf tissues using the PhytoPure ${ }^{\mathrm{TM}}$ Plant DNA Extraction Kit (GE Amersham Biosciences, Little Chalfont, UK).

Table 1 Percentage of nucleotide and amino acid sequence identities of MYMIV DNA-A and DNA-B with other begomoviruses and MYMIV isolates

\begin{tabular}{|c|c|c|c|c|c|c|c|c|c|c|c|c|c|}
\hline \multirow[t]{2}{*}{ DNA-A } & \multirow[t]{2}{*}{ Accession number } & \multicolumn{2}{|c|}{$\begin{array}{l}\text { Nucleotide } \\
\text { sequence } \\
\text { sequence } \\
\text { identity (\%) }\end{array}$} & \multicolumn{6}{|c|}{ Amino acid identity (\%) } & \multirow[t]{2}{*}{ DNA-B } & $\begin{array}{l}\text { Nucleotide seq. } \\
\text { identity }(\%)\end{array}$ & \multicolumn{2}{|c|}{$\begin{array}{l}\text { Amino acid } \\
\text { sequence } \\
\text { identity }(\%)\end{array}$} \\
\hline & & $\begin{array}{l}\text { Total } \\
\text { DNA }\end{array}$ & IR & V1 & $\mathrm{V} 2$ & $\mathrm{C} 1$ & $\mathrm{C} 2$ & $\mathrm{C} 3$ & $\mathrm{C} 4$ & & Total DNA & NSP & MP \\
\hline MYMIV-[PK:Cp:00] & AY269990 & 97.6 & 98.5 & 92.2 & 94.7 & 81.7 & 91.2 & 92.6 & 83.4 & _ & _- & _ & _ \\
\hline HYMV-[SL:LK:09] & GU323321 & 77.4 & 56.2 & 82.2 & 64.2 & 56.1 & 71.3 & 64.4 & 62.4 & GU323322 & 60.4 & 85.2 & 90.1 \\
\hline MYMIV-[IN:Cp:05] & DQ389154 & 98.9 & 99.2 & 98.7 & 96.1 & 88.4 & 90.1 & 91.7 & 92.8 & DQ389153 & 20.1 & 82.7 & 92.3 \\
\hline MYMIV-[IN:Var:Cp] & AY618902 & 93.8 & 98.5 & 98.1 & 97.2 & 90.1 & 92.3 & 90.1 & 93.1 & _- & _- & - & _- \\
\hline MYMIV-[NP:Lal:01] & AY271895 & 97.7 & 96.9 & 97.9 & 98.1 & 93.2 & 80.6 & 88.9 & 81.2 & _ & _- & _ & _- \\
\hline MYMIV-[PK:M175:01] & FM955598 & 98.8 & 100 & 99.1 & 98.7 & 87.3 & 88.9 & 92.7 & 93.6 & FM955603 & 91.1 & 89.9 & 96.7 \\
\hline MYMIV-[IN:Ako:01] & AY271893 & 95.2 & 98.5 & 95.2 & 92.7 & 89.1 & 86.2 & 93.3 & 90.8 & AY271892 & 91.7 & 89.9 & 94.7 \\
\hline MYMIV-[PK:130.12] & AJ512497 & 95.6 & 96.8 & 96.3 & 91.3 & 87.3 & 79.1 & 86.6 & 76.8 & - & - & - & - \\
\hline HgYMV-[IN:Coi:04] & AJ627904 & 77.5 & 58.5 & 84.1 & 64.4 & 55.1 & 71.3 & 65.9 & 62.4 & AJ627905 & 57.9 & 79.1 & 92.8 \\
\hline MYMV-[IN:Sb:99] & AF314530 & 77.6 & 55.4 & 82.7 & 65.6 & 59.1 & 74.2 & 67.1 & 59.1 & - & _ & - & _ \\
\hline MYMIV-[NP:Lal:03] & AY271895 & 97.7 & 96.9 & 93.7 & 94.1 & 90.2 & 88.6 & 91.3 & 93.4 & AY271894 & 91.7 & 88.7 & 75.2 \\
\hline MYMIV-[IN:Cp7:98] & AF481865 & 99.2 & 100 & 99.6 & 99.2 & 88.1 & 90.5 & 94.6 & 95.2 & AF503580 & 98.9 & 90.6 & 99.6 \\
\hline MYMIV-[IN:Sb2:99] & AY049772 & 95.2 & 100 & 99.1 & 98.3 & 90.2 & 91.6 & 92.8 & 93.9 & AY049771 & 23.3 & 95.3 & 99.6 \\
\hline MYMIV-[IN:Jab:01] & AJ416349 & 65.6 & 92.3 & 98.8 & 88.6 & 82.4 & 85.1 & 92.3 & 87.1 & AJ420331 & 91.3 & 82.6 & 96.1 \\
\hline MYMV-[IN:NamB1:05] & DQ865201 & 77.7 & 54.6 & 85.3 & 71.1 & 60.1 & 70.6 & 63.7 & 61.7 & DQ865202 & 84.8 & 76.9 & 96.1 \\
\hline VBSMV-[IN:Macu:09] & FN543425 & 70.1 & 85.7 & 89.5 & 56.1 & 51.8 & 56.6 & 43.2 & 46.6 & FN543426 & 41.2 & 30.8 & 42.6 \\
\hline CPGMV-[IN:Var:04] & AY618902 & 93.5 & 90.1 & 95.7 & 84.2 & 77.3 & 83.7 & 81.7 & 83.4 & - & _ & - & - \\
\hline RhYMIV-[IN:JRH9:10] & HM777509 & 67.4 & 91.2 & 88.4 & 55.3 & 50.7 & 44.1 & 39.9 & 51.1 & HM777510 & 42.5 & 31.4 & 42.4 \\
\hline KuMV-[VietNam:Fab:06] & DQ641690 & 65.7 & 53.7 & 80.2 & 49.1 & 41.4 & 52.1 & 43.3 & 60.7 & DQ641691 & 45.8 & 41.5 & 52.3 \\
\hline LYMV-[PK:14:02] & AJ512495 & 95.5 & 93.1 & 98.1 & 86.2 & 79.9 & 87.8 & 84.4 & 83.2 & - & - & - & - \\
\hline
\end{tabular}


Table 2 List of Mungbean yellow mosaic Inida virus obtained in this study and a summary of its features

Genomic components

\begin{tabular}{|c|c|c|c|c|c|c|c|c|c|c|}
\hline \multirow{3}{*}{ Virus } & \multicolumn{7}{|l|}{ DNA-A } & \multicolumn{3}{|l|}{ DNA-B } \\
\hline & \multirow{2}{*}{$\begin{array}{l}\text { GenBank } \\
\text { accession } \\
\text { no./clone } \\
\text { name }\end{array}$} & \multicolumn{6}{|c|}{$\begin{array}{l}\text { Conding sequences [coordinates/coding capacity (no. of amino acids)/predicted } \\
\text { molecular mass }(\mathrm{kDa}) \text { ] }\end{array}$} & \multirow[t]{2}{*}{$\begin{array}{l}\text { GenBank accession } \\
\text { no./clone name }\end{array}$} & \multicolumn{2}{|c|}{$\begin{array}{l}\text { Coding sequences } \\
\text { [coordinates/coding } \\
\text { capacity (no. of amino } \\
\text { acids)/predicted } \\
\text { molecular mass }(\mathrm{kDa})]\end{array}$} \\
\hline & & (A) $\mathrm{V} 2$ & $\mathrm{CP}$ & Ren & TrAP & Rep & (A)C4 & & NSP & MP \\
\hline \multirow[t]{2}{*}{ MYMIV } & JQ327845/MA2 & $156-497 /$ & $316-1089 /$ & 1086-1490/ & 1228-1668/ & 1776-2609/ & 2159-2458/ & JQ327848/RA45 & $329-1186 /$ & 1218-114/ \\
\hline & & $113 / 13.06$ & $257 / 29.96$ & $134 / 14.96$ & $146 / 15.57$ & $277 / 30.09$ & $99 / 10.99$ & & $285 / 32.88$ & $88 / 33.07$ \\
\hline MYMIV & JQ327846/MA3 & $\begin{array}{l}156-497 / \\
113 / 13.06\end{array}$ & $\begin{array}{l}316-1089 / \\
257 / 30.01\end{array}$ & $\begin{array}{l}1086-1490 / \\
134 / 15.57\end{array}$ & $\begin{array}{l}1228-1668 / \\
146 / 16.01\end{array}$ & $\begin{array}{l}1776-2609 / \\
277 / 30.08\end{array}$ & $\begin{array}{l}2159-2458 / \\
99 / 10.95\end{array}$ & - & - & - \\
\hline \multirow[t]{2}{*}{ MYMIV } & JQ327847/MA6 & $156-497 /$ & $316-1089 /$ & 1086-1490/ & 1228-1668/ & 1776-2609/ & 2159-2458/ & JQ327849/RA46 & $329-1186 /$ & 1218-2114/ \\
\hline & & $113 / 13.06$ & $257 / 29.93$ & $134 / 14.81$ & $146 / 15.57$ & $277 / 30.09$ & $99 / 10.79$ & & $285 / 32.76$ & $288 / 33.06$ \\
\hline
\end{tabular}

Begomovirus degenerate primers UPV1/UPC2 specific for DNA-A were used in PCR (Briddon and Markham 1994). A PCR product of the expected size (approximately $2.6 \mathrm{~kb}$ ) was amplified from all symptomatic plants, and no amplification products of the expected size were obtained from healthy or asymptomatic plants, confirming the association of a begomovirus with the disease. When used as a probe in Southern hybridization, a full-length clone of Tobacco leaf curl Japan virus detected characteristic viral DNA forms and further confirmed the association of begomovirus with the disease (results not shown). To sequence the remaining DNA region, additional specific primer pairs LMF/LMR (5'- a

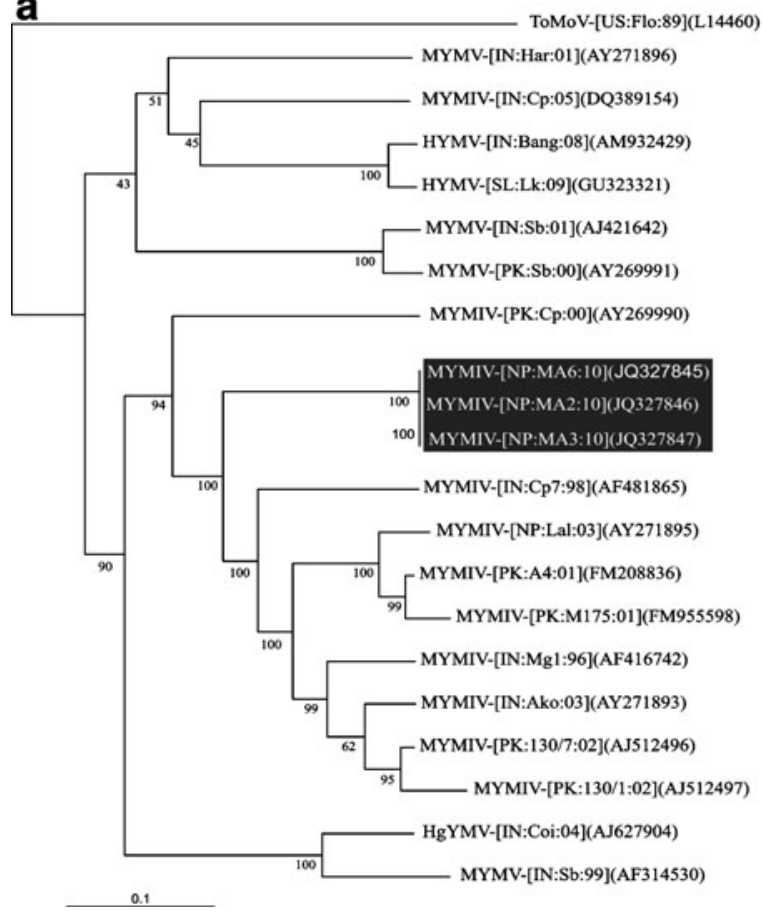

Fig. 2 Dendrogram derived from complete nucleotide sequences of selected DNA-A (a) and DNA-B (b) components of Phaseolus lunatus infecting begomoviruses and other Old World begomoviruses. The neighbor-joining method was used to construct the tree. Horizontal branch lengths are proportional to calculated mutation distances. Values below nodes represent percentage bootstrap values from 1,000 replicates. Both trees were arbitrarily rooted to the sequence of the b

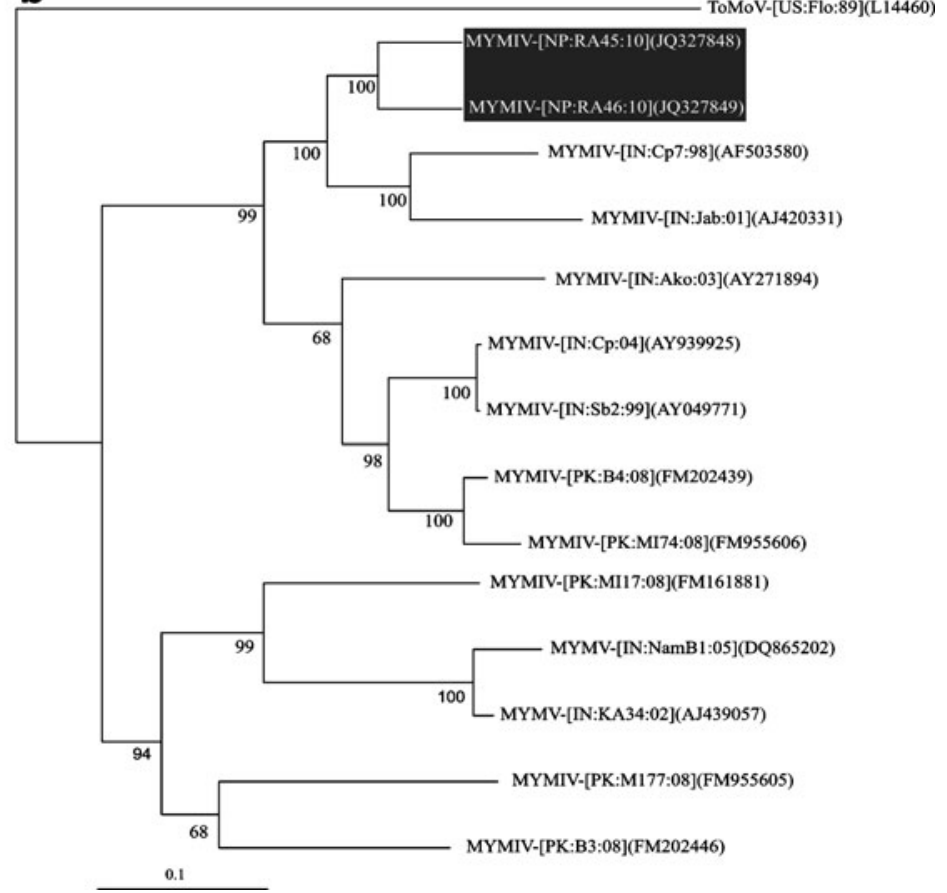

DNA-A component of ToMoV-[US:Flo:89]. Sequences used for bipartite begomovirus comparison are Mungbean yellow mosaic virus (MYMV), Mungbean yellow mosaic India virus (MYMIV), and Horsegram yellow mosaic virus (HgYMV). Isolate descriptors, where available, are as given in Fauquet et al. (2008). The database accession numbers are indicated for each isolate 
CTGCAGTGATGGGTCCCC-3'/5'-CTGCAGCTCAAG CATGGA- $3^{\prime}$ ) with the $P s t 1$ restriction site were designed and used for PCR to amplify the full-length begomovirus DNA-A component. PCR products of expected size was cloned into the pGEM $^{\circledR}$ T-vector (Promega). Rolling circle amplification (RCA) using \$29 DNA polymerase (Fermentas, Arlington, Canada) was performed to amplify DNA-B of bipartite begomovirus as described previously (Nahid et al. 2008). The RCA product was digested with different endonucleases (BamHI, SacI, SalI, NcoI, HindIII, KpnI, and XhoI). Approximately $2.7 \mathrm{~kb}$ fragment generated by $\mathrm{Bam} \mathrm{HI}$ was purified and cloned. Multiple clones were obtained by PCR/RCA, and a few clones from each amplification (both for DNA-A and the DNA-B) were selected and sequenced in their entirety in both orientations using a primer walking strategy by Macrogen, Tokyo, Japan. No DNA satellite was detected using DNA101/ DNA102 and bet01/bet02 specific primers for DNA satellites (Briddon et al. 2002; Bull et al. 2003). Sequences were assembled and analyzed with the aid of the Lasergene software package (DNAStar, Madison, WI, USA). Open reading frames (ORFs) were predicted with the ORF Finder online tool (http://www.ncbi.nlm.nih.gov/projects/gorf/) and GeneQuest software (Lasergene). Multiple sequence alignments were compiled with Clustal X (Thompson et al. 1997). Phylogenetic trees were constructed using the neighbor-joining method with Clustal X, and were displayed, manipulated and printed using Treeview (Page 1996).

The clones MA2, MA3 and MA6 (GenBank acc. no. JQ327845, JQ327846 and JQ327847) show 99.8\% sequence identity with each other and have genome organization similar to DNA-A component of a bipartite begomovirus originating from Old Word (OW). The three clones shared maximum nucleotide sequence identity of $99.2 \%$ with DNA-A component of MYMIV-[IN:CP7:98] (AF481865), followed by 98.9$65.6 \%$ identity with isolates of MYMIV-[PK:M175:01], MYMIV-[IN:Cp:05], MYMIV-[NP:La1:01], HYMV-[IN: Coi:04], MYMV-[IN:NamB1:05], HYMV-[SL:LK:09], LYMV-[PK:14:02], MYMIV-[IN:Ako:01], CPGMV-[IN: Var:04], MYMIV-[IN:Lal:03], VBSMV-[IN:Macu:09], RhYMIV-[IN:JRH9:10], KuMV-[VN:Fab:06] and MYMIV[IN:Jab:01] (Table 1). There is $99.6 \%$ sequence identity between the clones RA45 and RA46 (JQ327848 and JQ327849) . Which resemble the typical features of DNA-B component of bipartite begomovirus organization and showed maximum sequence identity of $98.9 \%$ with the cognate component of MYMIV-[IN:CP7:98] (AF503580) and only 91.7-20.1\% sequence identity with MYMIV-[IN:Ako:01], MYMIV-[IN:Lal:03], MYMIV-[IN:Jab:01], MYMIV-[PK: M175:01], MYMV-[IN:NamB1:05], HYMV-[SL:LK:09], HYMV-[IN:Co:04], MYMIV-[IN:CP7:98], MYMIV-[IN: Sb2:99], KuMV-[VN:Fab:06], RhYMIV-[IN:JRH9:10], VBSMV-[IN:Macu:09] and MYMIV-[IN:CP:05] (Table 1 and 2). Based on recently proposed criteria for distinguishing strains of begomoviruses (Fauquet et al. 2008) this indicates the the isolate from Nepal is of the "Indian" strain, for which we proposed the isolate descriptor Mungbean yellow mosaic Indian virus-India[Nepal:Chitwan:2010] (MYMIV-IN[NP: Chw:10]). The phylogenetic analysis of Nepal isolates group with the isolate of "India" strain that support the conclusion. (Fig. 2 a; DNA-A and b; DNA-B).

This is the first report of the occurrence of MYMIV in lima bean in natural condition in Nepal. MYMIV is an important pathogen of bean crops in India and has only a limited host range in Pakistan and Bangladesh, but does not seem to be a significant pathogen in Nepal where beans are widely distributed throughout the country. But recent study suggested the prevalence of this pathogen particularly in lima bean in Nepal. Most probably MYMIV spread from India because Chitwan is close to the Indian border and there is no physical barrier between them and whitefly can move freely between both countries or may be it has been disseminated through trade by land/air routes. Previous studies reflect the transfer of different viruses from neighboring countries because of trade or by dispersal of the whitefly vector (Ilyas et al. 2010). However, the viruses found in India and neighboring countries are often related owing to their geographical proximity and lack of natural barriers, which might be the case in the present situation (Shahid et al. 2007).

Acknowledgments This research was partly supported by an Advanced Research Project of the Nodai Research Institute, Tokyo University of Agriculture, Japan. The authors are also grateful to Mr. B.J. Pudashini (Master Student at Tokyo University of Agriculture) from Nepal for providing samples.

\section{References}

Briddon RW, Bull S, Mansoor S, Amin I, Markham P (2002) Universal primers for the PCR-mediated amplification of DNAbeta: a molecule associated with some monopartite begomoviruses. Mol Biotechnol 20:315-318

Briddon RW, Markham P (1994) Universal primers for the PCR amplification of dicot-lnfecting geminiviruses. Mol Biotechnol 2:202-205

Bull S, Briddon RW, Markham P (2003) Universal primers for the PCR-mediated amplification of DNA 1: a satellite-like molecule associated with begomovirus-DNA $\beta$ complexes. Mol Biotechnol 23:83-86

Dry I, Rigden J, Krake L, Mullineaux P, Rezaian M (1993) Nucleotide sequence and genome organization of tomato leaf curl geminivirus. J Gen Virol 74:147-151

Fauquet CM, Briddon R, Brown J, Moriones E, Stanley J, Zerbini M, Zhou X (2008) Geminivirus strain demarcation and nomenclature. Arch Virol 153:783-821

Hanley-Bowdoin L, Settlage S, Robertson D (2004) Reprogramming plant gene expression: a prerequisite to geminivirus DNA replication. Mol Plant Pathol 5:149-156

Hussain M, Mansoor S, Iram S, Zafar Y, Briddon RW (2007) The hypersensitive response to tomato leaf curl New Delhi virus 
nuclear shuttle protein is inhibited by transcriptional activator protein. Mol Plant-Microbe Interact 20:158-1588

Ilyas M, Javaria Q, Mansoor S, Briddon RW (2010) Genetic diversity and phylogeography of begomoviruses infecting legumes in Pakistan. J Gen Virol 91:2091-2101

Nahid N, Amin I, Mansoor S, Rybicki E, van der Walt E, Briddon RW (2008) Two dicot-infecting mastreviruses family Geminiviridae occur in Pakistan. Arch Virol 153:1441-1451

Page RDM (1996) TREEVIEW: An application to display phylogenetic trees on personal computers. Comput Appl Biosci 12:357-358

Saeed M, Mansoor S, Rezaian M, Briddon RW, Randles J (2008) Satellite DNA beta overrides the pathogenicity phenotype of the C4 gene of Tomato leaf curl virus, but does not compensate for loss of function of the coat protein and V2 genes. Arch Virol 153:1367-1372
Settlage SB, See RG, Hanley-Bowdoin L (2005) Geminivirus C3 protein: replication enhancement and protein interactions. J Virol 79:9885-9895

Shahid MS, Mansoor S, Briddon RW (2007) Complete nucleotide sequences of cotton leaf curl Rajasthan virus and its associated DNA $\beta$ molecule infecting tomato. Arch Virol 152:2131-2134

Stanley J, Bisaro DM, Briddon RW, Brown JK, Fauquet CM, Harrison BD, Rybicki EP, Stenger DC (2005) In: Fauquet CM, Mayo MA, Maniloff J, Desselberger U, Ball A (eds) Virus Taxonomy, 5th report of the ICTV. Elsevier/Academic Press, London, pp 301326

Thompson JD, Plewniak F, Jeanmougin F, Higgins DG (1997) The Clustal X windows interface; flexible strategies for multiple sequence alignment aided by quality analysis tools. Nucleic Acids Res 25:4876-4882 